\title{
Cardiac Granuloma
}

National Cancer Institute

\section{Source}

National Cancer Institute. Cardiac Granuloma. NCI Thesaurus. Code C9274.

A granuloma located in the myocardium. 